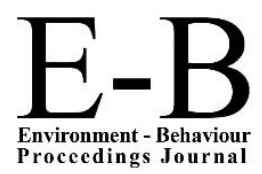

\title{
AicE-Bs2016Edinburgh
}

$7^{\text {th }}$ Asia-Pacific International Conference on Environment-Behaviour Studies, St Leonard Hall, Edinburgh University, United Kingdom, 27-30 July 2016

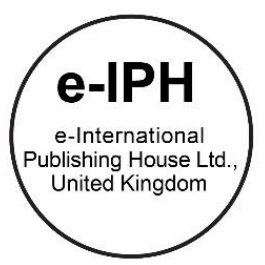

\section{Does Learning Organization Lead to a Better Performance?: A Study of a GLC in Malaysia}

\author{
Norashikin Hussein ${ }^{*}$, Ainie Hairianie Aluwi ${ }^{2}$, Fauziah Noordin ${ }^{3}$, Noormala Amir Ishak ${ }^{4}$ \\ $12{ }^{4}$ Centre of Management and Administrative Studies, Faculty of Business and Management, Universiti Teknologi MARA, Puncak Alam \\ Campus, 42300 Bandar Puncak Alam, Selangor, Malaysia \\ ${ }^{3}$ Centre for Postgraduate and Professional Studies, Faculty of Business and Management, Universiti Teknologi MARA, Shah Alam, Selangor, \\ Malaysia
}

\begin{abstract}
The Government-linked Companies (GLCs) transformation program is aimed to ensure its competency and competitiveness in achieving the nation's Vision 2020. One of the factors that lead to higher performance is through the development of learning organization which provides continuous learning and improvement, directly linked to competitive advantage. Data collected from 150 employees of a telecommunication GLC in Malaysia revealed that three of learning organization dimensions namely; systems connection, strategic leadership and team learningwere positively related to organizational performance. This study is significant to GLCs top management and the Malaysian government in ensuring superior performance in a knowledge-driven economy.
\end{abstract}

(C) 2016. The Authors. Published for AMER ABRA by e-International Publishing House, Ltd., UK. This is an open access article under the CC BYNC-ND license (http://creativecommons.org/licenses/by-nc-nd/4.0/).

Peer-review under responsibility of AMER (Association of Malaysian Environment-Behaviour Researchers), ABRA (Association of Behavioural Researchers on Asians) and CE-Bs (Centre for Environment-Behaviour Studies), Faculty of Architecture, Planning \& Surveying, Universiti Teknologi MARA, Malaysia..

Keywords: learning organization, organizational performance

\section{Introduction}

In today's fast-paced economy, most organizations face tremendous challenges as a result of the rapid advancement of information and knowledge. The challenges brought by the knowledge economy suggest that organizations need to be ready for an immense increase in the demand for better services and performance, in line with the changing business environment. Government-linked companies (GLCs) in Malaysia have played an imperative role in shaping the economic structure of Malaysia (Bhatt, 2016). Not only they have been the backbone

\footnotetext{
* Corresponding author. Tel.: +6019-7254231

E-mail address:shikin6320@salam.uitm.edu.my
}

2398-4287 @ 2016. The Authors. Published for AMER ABRA by e-International Publishing House, Ltd., UK. This is an open access article under the CC BY-NC-ND license (http://creativecommons.org/licenses/by-nc-nd/4.0/).

Peer-review under responsibility of AMER (Association of Malaysian Environment-Behaviour Researchers), ABRA (Association of Behavioural Researchers on Asians) and CE-Bs (Centre for Environment-Behaviour Studies), Faculty of Architecture, Planning \& Surveying, Universiti Teknologi MARA, Malaysia.

DOI: http://dx.doi.org/10.21834/e-bpj.v1i4.180 
of the nation's economy, but they also play a major presence in the corporate sector in Malaysia. GLCs in Malaysia are defined as companies that have a primary commercial objective and in which the Malaysian Government has a direct controlling stake through Khazanah, Ministry of Finance (MOF), Kumpulan Wang AmanahPencen (KWAP), and Bank Negara Malaysia (Md. Boni, 2014). GLCs comprised of 41 per cent of the market capitalization of Bursa Malaysia and also represented 4 percent of total listed companies with market capitalization of 49 per cent of Kuala Lumpur Composite Index.

Since the Malaysian Government's initiative is to transform the GLCs to be high-performance organizations, the GLCs are expected to be highly competitive and able to adapt to the rapidly changing business environment. Indeed, Bhatt (2016) perceived the GLCs transformation program as a platform for an improved performance for the organizations to be more successful. However, the major achievements found in GLCs are mostly of growth and profitability, resulting in the lack of effective performance from other non-financial aspects (Nazrul, Rubi \& Huson, 2011). As human resources are highly regarded as important assets in GLCs, developing high-quality human capital that are knowledgeable and highly skilled are imperative for their performance and survival. As a result, learning has become a central element in most organizations. Thus, the interest in the development of learning organization is not an end in itself but a route to improve performance and organizational effectiveness (Marsick \& Watkins, 2003).

Learning organization is one that learns continuously and converts itself. It proactively uses learning in an incorporated way to support and catalyze development for persons, groups, whole organizations, the institutions, and communities with which they are associated (Watkins \& Marsick,1993; Marsick \& Watkins, 2003). In fact, learning organization is a well-established concept (Ellinger, Ellinger, Yang, \& Howton, 2002) associated with the field of organizational change and development, strategic management and human resource development in managing effective organizational performance (Weldy, 2009). Specifically, literatures have confirmed that learning organization resulted in positive outcomes such as better performance (Kamariah, 2006; Kumar, 2005; Norashikin, Safiah, Fauziah, \& Noormala, 2016; Pokharel \& Sang, 2015; Yeo, 2003); innovation (e.g., Liao, 2006; Meriam, 2005; Sta Maria, 2000), work engagement (Anitha, 2014; Norashikin, Nurain \& Muhamad Khalil, 2016) and organizational commitment (e.g., Atak \& Erturgut, 2010).In another word, becoming a learning organization is one of the best ways an organization can improve their practices and be high performing organizations in order to increase their effectiveness.

Despite its importance, a few researchers (Pokharel \& Sang, 2015; Weldy, 2009) contend on the scarce studies on learning organization, and further question how it links to organizational performance, empirically. Particularly, Kamariah (2006), Kumar (2005) and Norashikin, Amnah, Fauziah and Noormala (2014) highlight its limited evidence in the Malaysian context.Therefore, the objective of the study is to determine the relationship between learning organization and organizational performance.

\section{Literature Review}

\section{Learning Organization}

The concept of learning organization was developed from the term 'organizational learning' (Yang \& Qu, 2007). The idea of learning organization derived from an effort to find the key in maximizing competitiveness for business survival (Kleiner, 1999). The concept of the learning organization was driven by Senge (1990), who popularized the concept. According to Senge (1990), over the past two years, business scholars and senior managers have begun speaking about the idea of the learning organization. Senge (1990) defined learning organization as organizations where individuals continually develop their capability to generate the outcomes they truly desire, where new and extensive arrangements of thinking are encouraged, where collective aspiration is set free, and where people are continually learning how to learn together. He also said that there are five dimensions of learning organization which consists of systems thinking, personal mastery, mental models, shared vision, and team learning. The integrative perspective of a learning organization developed by Watkins and Marsick (1993) who identified seven interrelated dimensions of the concept of individual, team, and organizational levels. The seven dimension of the learning organization is divided these three levels. 
The dimension of continuous learning; and Inquiry and dialogue are identified under individual level. Meanwhile, the team learning represents the team or group level. At the organizational level, it is consisted of four dimensions of learning organization which is empowerment, environmental connection, embedded system and strategic leadership (Yang, Watkins, \& Marsick, 2004). The definition of each learning organization dimension used in the study is at Table 1.

Table 1.Learning Organization Dimensions

\begin{tabular}{|c|c|c|}
\hline Dimensions & $\begin{array}{l}\text { Level of } \\
\text { Learning }\end{array}$ & Definition \\
\hline Continuous Learning & Individual & $\begin{array}{l}\text { Learning is designed into each employee work in order to give them opportunity to learn on the } \\
\text { job, and to continue education and keep growth }\end{array}$ \\
\hline Inquiry and Dialogue & Individual & $\begin{array}{l}\text { People are gained productive skills to express their views and their capacity to listen to other } \\
\text { views. This culture is to support questioning, feedback, and experimentation. }\end{array}$ \\
\hline Team Learning & Team & $\begin{array}{l}\text { Defined as the work designed to groups to access the different modes of thinking, ideas, and } \\
\text { expected to learn and work together. }\end{array}$ \\
\hline Embedded System & Organization & $\begin{array}{l}\text { Both the high and low technology system is use to share learning and integrated with work to } \\
\text { provide an access to all. }\end{array}$ \\
\hline Empowerment & Organization & $\begin{array}{l}\text { Defined when the organizations get the people to be involved in setting, owning and joint } \\
\text { vision. This is decision making that makes together will motivated people to learn toward what } \\
\text { they are responsible to do. }\end{array}$ \\
\hline Strategic Leadership & Organization & $\begin{array}{l}\text { Defined as the leaders' model, champion and to support learning to use the learning } \\
\text { strategically as the business results. }\end{array}$ \\
\hline $\begin{array}{l}\text { Environmental } \\
\text { Connection }\end{array}$ & Organization & $\begin{array}{l}\text { The environment is to help the people to see the effect of their work and use the environment } \\
\text { as information to adjust the work practices and make the organization linked to the } \\
\text { communities. }\end{array}$ \\
\hline
\end{tabular}

Source: Marsick \& Watkins (2003).

\section{Dimensions of the Learning Organization and Organizational Performance}

The organizational performance concept is tough and hard to be conceptualized and has been measured in various ways based on its context (Stankard, 2002). Venkatraman and Ramanujan (1986) for example suggested that in measuring performance, there are three aspects to be considered, among them are: financial performance, business performance, and organization effectiveness. This study, however, adopted Griffin's (2003) stand on organizational performance, as the level to which organization capable of fulfilling the needs of their stakeholders and its survival.

Emerging research supports the significance of learning organization dimensions and the impact it has on organizational performance. A study conducted by Norashikin et. al. (2016) among 40 academics in a public institution of higher education in Malaysia revealed that continuous learning is strongly correlated with organizational performance while team learning was found to be the strongest predictor of organizational innovativeness. Pokharel and Sang (2015) in a study of a public service organization confirmed the link between learning organization level of dimensions especially system connection and organizational performance. A study by Akhtar, Arif, Rubi and Naveed (2011), found two dimensions of the learning organization that leads to higher performance, namely inquiry and dialogue, and environmental connection. The remaining dimensions of learning organization culture do not have any link with organizational performance. Continuous learning, however, was found to have the greater influence on individual performance rather than organizational performance. Other studies (e.g., Bontis, Crossan, \& Hulland, 2002; Kandekar \& Sharma, 2006) relate the development of learning organization with higher financial performance. H1: There is a positive relationship between learning organization (continuous learning, inquiry and dialogue, team learning, embedded system, empowerment, strategic leadership and environmental connection) and organizational performance. 


\section{Theoretical Framework}

The study examines the relationship between learning organization and organizational performance. These relationships are displayed as Figure 1, which shows learning organization as the independent variable, with seven dimensions namely continuous learning, inquiry and dialogue, team learning, embedded system, empowerment, strategic leadership and environmental connection.

Figure 1. Theoretical Framework

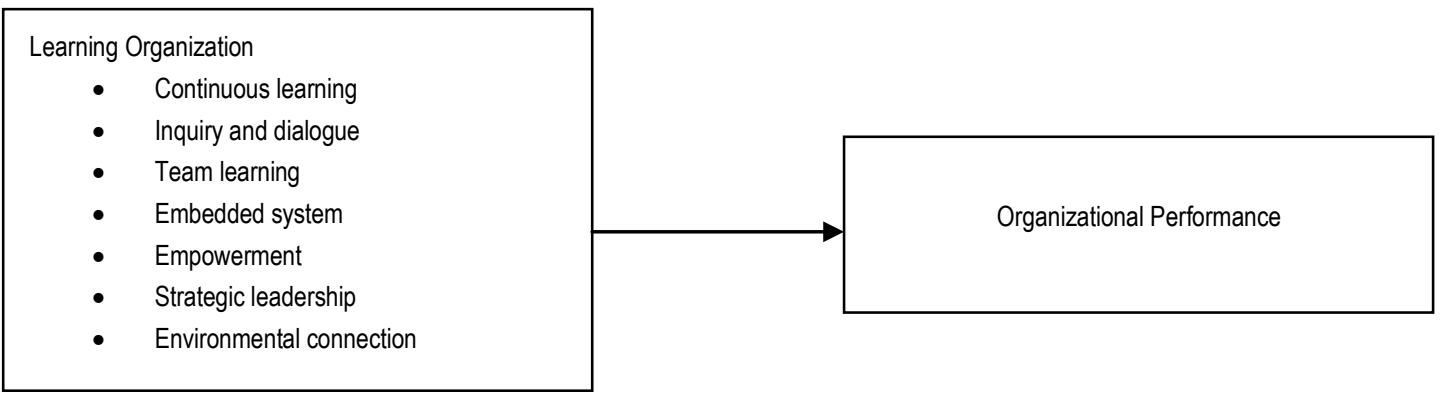

\section{Methodology}

The study utilized a cross-sectional research design using in analyzing the relationships between learning organization dimensions and organizational performance. Data were collected from employees of a telecommunication GLC in Klang Valley, Malaysia. Before the data collection, the organization was contacted, to seek for permission. Questionnaires were distributed using 'drop off and collect' method with the person-in-charge in the organization coordinating the distribution of the questionnaires. Instruments used in the study were from established sources and had proven to demonstrate high-reliability values. The short version of Dimensions of Learning Organization Questionnaires (DLOQ) from Yang et. al. (2004) was utilized to measure learning organization. Specifically, the instrument consisted of 21 items, covering seven dimension of learning organization which is continuous learning ( 3 items), inquiry and dialogue ( 3 items), team learning ( 3 items), namely empowerment ( 3 items), environmental connection ( 3 items), embedded system ( 3 items) and strategic leadership ( 3 items). All items were measured using five-point Likert scales ranged from 1 to 5 ( $1=$ Never to $5=$ Always). Meanwhile, in measuring organizational performance, seven items proposed by Ramayah, Nusrah, and Lo (2011) were utilized. The items asked the respondents to rate their organization's performance in their market segment over the past three years particularly on a number of complaints, return on investment, financial performance, sales growth, productivity, customer satisfaction and employee satisfaction. The measure five-point Likert scale ranged from 1 to 5 (1= Greatly Decreased to $5=$ Greatly Increased). Eight items on demographics were also included in the questionnaire, amongst are gender, age, ethnicity, education level, marital status, level of the organization, the length of service and time spent on work-related learning. Data were analyzed using Statistical Package for the Social Sciences Software (SPSS).

\section{Findings}

Data was collected from 150 employees, yielding a response rate of 60 percent. The majority of the respondents were female with 113 respondents $(75.3 \%)$, and 36 respondents $(24.7 \%)$ were males. Slightly half of the 
respondents were aged between 21 to 30 years old with the frequency of $83(55.3 \%)$, followed by 41 to 50 years old $(24 \%)$ and 31 to 40 years old $(20.7 \%)$.The majority of the respondents were Malay (96.7\%), and most are married respondents $(56 \%)$. The majority of the respondents hold a bachelor's degree $(65.3 \%)$ or masters degree $(22 \%)$. The respondents comprised of level with frequency of $62(41.3 \%)$, followed by respondents at the manager level with frequency of $27(18 \%)$, respondents at senior executive level with frequency of $25(16.7 \%)$, respondents at nonexecutive level with frequency of $20(13.3 \%)$, respondents at assistant manager level with frequency of $16(10.7 \%)$. However, there are no respondents from senior management. 36.7 percent of the respondents have worked with the organization for 1 to 3 years, followed by five years tenure $(30.7 \%)$. For the time spend on work-related learning, most of the respondents spent 1 to 10 hours per month for training (58\%), followed by 11 to 20 hours of training per month with a frequency of $41(27.3 \%)$.

Reliability analysis was conducted on all variables. Based on the results, the reliability values ranged from .85 to .97 which indicates that the variables used in the study have high consistencies and very reliable. Based on the results in Table 2, it was found that all variables have mean values ranged from 3.63 (organizational performance) to 3.92 , with continuous learning has the highest mean value. The ranged of standard deviation among variables is reported between .70 (organizational performance) to .83 (empowerment).Table 3 showed inter-correlation values among variables. It was found that all dimensions of learning organization significantly related to organizational performance inter-correlated ranging from $r=.62$ to $r=.80$. Specifically, The strongest association is between environmental connection and organizational performance $(r=.795, p<0.01)$, followed by leadership $(r=.794, p<0.01)$, empowerment $(r=.748, p<0.01)$, team learning $(r=.722, p<0.01)$, embedded system $(r=.694, p<0.01)$, inquiry and dialogue $(r=.682, p<0.01)$ and lastly continuous learning $(r=.617, p<0.01)$.

Table 2.Means and Standard Deviations

\begin{tabular}{|c|c|c|}
\hline Variables & Mean & Standard Deviation \\
\hline Organizational Performance & 3.63 & .70 \\
\hline \multicolumn{3}{|l|}{ Learning organization } \\
\hline Continuous Learning & 3.92 & .80 \\
\hline Inquiry and dialogue & 3.83 & .72 \\
\hline Team Learning & 3.69 & .73 \\
\hline Embedded System & 3.79 & .75 \\
\hline Empowerment & 3.63 & .83 \\
\hline Environmental Connection & 3.78 & .78 \\
\hline Strategic Leadership & 3.81 & .78 \\
\hline
\end{tabular}

Table 3 Intercorrelations among Variables

\begin{tabular}{|c|c|c|c|c|c|c|c|c|}
\hline Variables & $\begin{array}{c}\text { Organizational } \\
\text { Performance }\end{array}$ & $\begin{array}{c}\text { Continuous } \\
\text { Learning }\end{array}$ & $\begin{array}{l}\text { Inquiry \& } \\
\text { Dialogue }\end{array}$ & $\begin{array}{c}\text { Team } \\
\text { Learning }\end{array}$ & $\begin{array}{c}\text { Embedded } \\
\text { System }\end{array}$ & Empowerment & $\begin{array}{c}\text { Environmental } \\
\text { Connection }\end{array}$ & $\begin{array}{c}\text { Strategic } \\
\text { Leadership }\end{array}$ \\
\hline $\begin{array}{l}\text { Organizational } \\
\text { Performance }\end{array}$ & 1 & & & & & & & \\
\hline $\begin{array}{l}\text { Continuous } \\
\text { learning }\end{array}$ & $.617^{\star *}$ & 1 & & & & & & \\
\hline $\begin{array}{l}\text { Inquiry \& } \\
\text { Dialogue }\end{array}$ & $.682^{* *}$ & $.836^{\star *}$ & 1 & & & & & \\
\hline Team Learning & $.722^{\star *}$ & $.754^{* *}$ & $.856^{\star *}$ & 1 & & & & \\
\hline $\begin{array}{l}\text { Embedded } \\
\text { system }\end{array}$ & $.694^{\star *}$ & $.711^{\star *}$ & $.776^{\star \star}$ & $.776^{\star *}$ & 1 & & & \\
\hline Empowerment & $.748^{* *}$ & $.637^{\star \star}$ & $.794^{* *}$ & $.812^{\star \star}$ & $.764^{\star *}$ & 1 & & \\
\hline
\end{tabular}




\begin{tabular}{|c|c|c|c|c|c|c|c|c|}
\hline $\begin{array}{c}\text { Environmental } \\
\text { Connection }\end{array}$ & $.795^{* *}$ & $.639 * *$ & $.748^{* *}$ & $.743^{* *}$ & $.720^{* *}$ & $.853^{\star *}$ & 1 & \\
\hline $\begin{array}{c}\text { Strategic } \\
\text { Leadership }\end{array}$ & $.794^{* *}$ & $.680^{* *}$ & $.806^{* *}$ & $.778^{* *}$ & $.888^{* *}$ & $.856^{\star *}$ & $.879^{* *}$ & 1 \\
\hline
\end{tabular}

${ }^{*} p<0.05,{ }^{* *} p<0.01$

Based on Table 4, the model which includes continuous learning, inquiry and dialogue, team learning, embedded system, empowerment, environmental connection and leadership explained learning organization as having 69 percent of the variance in organizational performance. Of these seven dimensions of the independent variables, strategic leadership has the most positive significant relationship with organizational performance $(B=.39$, $p<0.01)$. This indicates that strategic leadership was the strongest predictor of organizational performance. An environmental connection was found to be the second highest contributor to organizational performance $(B=.34$, $p<0.01)$, followed by team learning $(B=.25, p<0.05)$. Continuous learning, inquiry and dialogue, embedded system and empowerment did not predict organizational performance. Therefore, $\mathrm{H} 1$ is partially supported.

Table 4: Regression analysis

\begin{tabular}{lc}
\hline Independent Variables & $\begin{array}{c}\text { Dependent Variable } \\
\text { Organizational Performance (B) }\end{array}$ \\
\hline Learning organization & .114 \\
Continuous Learning & -.173 \\
Inquiry and Dialogue & $.250^{\star}$ \\
Team Learning & -.065 \\
Embedded System & .040 \\
Empowerment & $.336^{* \star}$ \\
Environmental Connection & $.390^{* \star}$ \\
Strategic eadership & $45.93^{* \star}$ \\
\hline Fvalue & .694 \\
R square & .679 \\
Adjusted R square & \\
\hline
\end{tabular}

\section{Discussion}

The objective of the study is to determine the relationship between learning organization (continuous learning, inquiry and dialogue, team learning, embedded system, empowerment, strategic leadership and environmental connection) and organizational performance. The findings revealed that two dimensions at the organizational level namely strategic leadership and environmental connection have a positive significance influence on organizational performance. Additionally, team learning which represents the learning at the group level was also found to have the positive significant relationship with organizational performance. No relationship was found between continuous learning, inquiry and dialogue; embedded system and empowerment; and organizational performance.

At the organizational level, learning involves more than just learning committees and activities (Pokharel \& Sang, 2015). Learning is more comprehensive involving shared understanding and institutionalized values and norms that able the organization to strive for change and improvement (Wang \& Ahmed, 2003). Specifically, leaders in the organization play an important role in providing the subordinates direction on how to achieve their goals, which will directly impact on their performance. Strategic leadership goes beyond that by rearranging resources and capabilities of the organization to achieve competitive advantage (Barney, 1991). In fact, strategic leadership can influence and mold the culture of the organization through ritual, symbols, boundaries and reward system for better 
organizational performance (Vera \& Crossan, 2004). It is through the strategic leadership of an organization that the culture of learning is inculcated among employees in the organization (Senge, 1990). Since performance involved a long-term initiative, strategic leadership need to be continuously sustained to ensure positive performance results. Meanwhile, environmental connection provides perspective for employees to see the effect of their effort to the environment and communities (Marsick \& Watkins, 2003). Similar to a finding obtained by Pokharel and Sang (2015), environmental connection ensures employees to understand their contributions to the communities. Once they understand their role in the environment, work is more productive, and there is the higher willingness in providing the best performance to the organization.

Learning at the group level is seen as an on-going process involving group process (Watkins \& Marsick, 1993). Team Learning is developed when members of the team share and learn new knowledge, skills and perspectives. Even though individuals in the team may start off differently, going through an on-going capacity and continuous effort, teams can work efficiently (Pokharel \& Sang, 2015). When the member of the teams are supportive and trust each other, it will lead to a great team performance. Through effective team collaboration, common goals set by the organization can be achieved (Watkins \& Marsick, 2003).

\section{Implication, Limitation, and Conclusion}

The significance of the study relies on its contribution to the body of knowledge as it adds to the existing literature on learning organization and organizational performance. Even though the link between the two variables is established, more evidence especially empirical data is needed to understand the phenomenon. In fact, it has been highlighted previously that there has been a gap in the Malaysian context. Therefore, this study is hoped to bridge the gap by providing empirical evidence on learning organization and organizational performance, specifically in the context of GLC in Malaysia.

The study also provides practical implication to the top management of the GLCs and the Malaysian government on the learning organization attributes that would help to promote effective performance for the organization. Firstly, it is imperative to take note that change is inevitable, and learning is important for the organizations to adapt to the rapidly changing business environment. Since leaders are the key people that drive and chart the direction of the organization, attention should be paid to the strategic roles of leaders to lead learning in maximizing the organizational performance. Secondly, employees in GLC need to not only know that the organization they are working for contributes significantly to the nation's economy but also the effect of their individual job to the communities. Once they understand the 'environmental connection' they are more open to learning and this would contribute to the organizational performance as a whole. Lastly, perhaps, learning at team level should be utilized more often in the GLC context as collaborative sharing and learning are perceived as an important factor that would lead improved organizational performance.

The study can be better improved in many ways. Firstly, it is suggested that future study should extend its sample to various GLCs in Malaysia for the findings to highly generalize. Secondly, studies that are organization based (i.e., learning organization) should utilize longitudinal study design as perceptions on it may be captured more efficiently across time. Lastly, if possible, the moderating or mediating variable should be included in future to enable the researcher to understand better the dynamic framework between learning organization and organizational performance.

The study highlights the specific dimensions namely strategic leadership, environmental connection and team learning of learning organization that would influence effective organizational performance. The findings offer valuable and practical insights for not only researchers but also practitioners on learning organization mechanism that would lead to superior performance among GLCs in Malaysia 


\section{Acknowledgements}

The authors would like gratefully acknowledge research support under the Research Acculturation Grant Scheme (RAGS), administered by Universiti Teknologi MARA and funded by the Malaysian Government.

\section{References}

Akhtar, S., Arif, A., Rubi, E., \& Naveed, S. (2011). The impact of Learning on Organizational Performance: Study of Higher Education Institutes. International Journal of Academic Research, 3(5), 327-331.

Anitha, J. (2014). Determinants of employee engagement and their impact on employee performance. International Journal of Productivity and Performance Management, 63(3), 308-323.

Atak, M., \& Erturgut, R. (2010). An empirical analysis on the relation between learning organization and organizational commitment. Procedia Social and Behavioural Sciences, 2, 3472-3476.

Barney, J. (1991). Firm resources and sustained competitive advantage. Journal of Management, 17, 99-120.

Bhatt, P. R. (2016). The performance of government-linked companies and private owned companies in Malaysia, International Journal of Law and Management, 58(2), $150-161$.

Bontis, N., Crossan, M., \& Huallnd, J. (2002). Managing an Organizational Learning System by Aligning Stocks and Flows. Journal of Management Studies, 39(A), 437-469.

Ellinger, A. D., Ellinger, A. E., Yang, B., \& Howton, S. W. (2002). The relationship between the learning organization concept and firms' financial performance: An empirical assessment. Human Resource Development Quarterly, 13, 5-21.

Garvin, D. A. (1993). Building a learning organization. Havard Business Review, July-August, 78-91.

Griffin, M. (2003), "Organizational performance model", available at: http://griffin-oc.com/GOC_Organizational_Performance_Model.pdf (accessed October, 2015)

Kamariah, N. (2006). The perceived influence of the learning environment on organizational knowledge creation process and knowledge performance in public research and development organizations in Malaysia. Unpublished Ph.D. Thesis. Universiti Teknologi MARA.

Kandekar, A., \& Sharma, A. (2006). Organizational Learning and Performance: Understanding Indian Scenario in Present Global Context. Education and Training, 48(9), 682-692.

Kleiner, A. (1999). Chronology of learning-organization concepts. Fast Company, 180-188.

Kumar, N. (2005). The relationship between LO dimensions and performance among Malaysian private institution of higher learning. Unpublished Ph.D. Thesis. Universiti Putra Malaysia.

Liao, L. (2006). A learning organization perspective on knowledge-sharing behavior and firm innovation. Human Systems Management, 25(4), 227-236.

Marsick, V. J., \& Watkins, K. E. (2003). Demonstrating the value of an organization's learning culture: The dimensions of the learning organization questionnaire. Advances in Developing Human Resources, 5, 132-151.

Md. Boni, A. (2014). A study on Government Linked Company in Malaysia: A critical analysis.

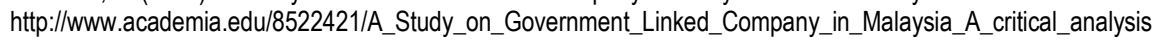

Meriam, I. (2005). Creative climate and learning organization factors: Their contribution towards innovation. Leadership \& Organization Development Journal, 26, 639-654.

Nazrul, H. A., Rubi, A. \& Huson, A. J. (2011). Does Government Linked Companies (GLCs) perform better than on-GLCs? Evidence from Malaysian listed companies, Journal of Applied Finance \& Banking, 1(1), 213-240

Norashikin, H., Safiah, O. Fauziah, N., \& Noormala A. I. (2016). Learning Organization Culture, Organizational Performance and Organizational Innovativeness in a Public Institution of Higher Education in Malaysia: A Preliminary Study. Procedia Economics, and Finance, 37, 512 - 519. 
Norashikin, H. , Nurain, A. \& Muhamad Khalil, O. (2016, May), Learning Organization And Work Engagement: An Empirical Evidence Of A Higher Learning Institution In Malaysia, Paper presented at International Conference of Research Methods in Management and Social Sciences, Makassar, Indonesia.

Norashikin, H., Amnah, M., Fauziah, N., \& Noormala, A. I. (2014). Learning organization and its effect on organizational performance and organizational innovativeness: A proposed framework for Malaysian Public Institutions of Higher Education, Procedia-Social and Behavioral Sciences, 130, 299-304

Pokharel, M. P. \& Sang, O. K. (2015). Exploring the relationships between the learning organization and organizational performance, Management Research Review, 38 (2), 126-14

Ramayah, T., Nusrah, S. \& Lo, M. C. (2011). Market Orientation, Service Quality And Organizational Performance In Service Organizations In Malaysia, Asia-Pacific Journal of Business, 3(1), 8-27

Senge, P. M. (1990). The Fifth Discipline: The Art And Practice Of The Learning Organization. New York: Doubleday.

Sta. Maria, R. F. (2000). Perception of learning culture concerns about the innovation, and their influence on the use of an on-going innovation in the Malaysian public sector. Unpublished doctoral thesis. University of Athens, Georgia.

Stankard, M. F. (2002). Management Systems and Organizational Performance: The Search for Excellence Beyond ISO9000. Westport, CT: Greenwood Publishing Group.

Venkatraman, N. \& Ramanujan, V. (1986). Measurement of business performance in strategy research: a comparison of approaches, Academy of Management Review, 11(4), 801-14.

Vera, D., \& Crossan, M. (2004). Strategic leadership and organizational learning. Academy of Management Review, 29, $222-240$.

Wang, C. L., \& Ahmed, P. K. (2003). Organizational learning: A critical review. The Learning Organization, 10, 8-17.

Watkins, K. E., \& Marsick, V. J. (1993). Sculpting The Learning Organization. San Francisco: Jossey-Bass.

Weldy, T. (2009), Learning organization and transfer: strategies for improving performance, The Learning Organization, 16(1), 58-68.

Yang, B., \& Qu, Q. (2007). Learning Organization: A review of Conceptualizations and Empirical Evidence. Paper presented at the 6th International Conference of the Academy of HRD (Asia Chapter), Beijing, China.

Yang, B., Watkins, K. E., \& Marsick, V. J. (2004). The construct of The Learning Organization: Dimensions, Measurement, and Validation. Human Resource Development Quarterly, 15, 31-55.

Yeo, R. (2003). Linking organizational learning to organizational performance and success: Singapore case studies. Leadership \& Organization Development Journal, 24, 70-83. 